\title{
Proof of Native Title: A Level Playing Field?
}

\author{
John R. Forbes
}

D

espite intense professional and media discussion of the Mabo movement in Australia, remarkably little attention has been given to two eminently practical questions. What will the actual process of proof and adjudication be like? And what will be done to ensure that the fruits of successful native-title claims are honestly and fairly distributed to all members of the claimant group? This article seeks to attract attention to the first of these issues.

In $M a b o$, the High Court grafted a vaguely defined concept of 'native title' on to the common law of Australia. This was done, so we were told, to comply with the 'expectations of the international community' and the 'contemporary values of the Australian people'. 'The decision has led to expectations of greatly increased benefits, enhanced powers for publicly funded Aboriginal bodies, and quasi-evangelical promises of 'reconciliation'.

The ambitions of some members of the burgeoning federal judiciary are apparently no longer satisfied by traditional judicial tasks. Mason CJ (1993:23) has argued, 'I think that in some circumstances, governments . . . prefer to leave the determination of controversial questions to the courts rather than ltol . . . the political process. Mabo is an interesting example.' A former Federal Court judge puts it more directly: 'The Court has constructed, from really nothing, a completely new doctrine' (Jackson, 1994:211). Perhaps Mabo was never intended to be selfsufficient, but to provide an impulse (or excuse) for federal legislation notwithstanding the 'land rights' schemes that already existed in the Northern Territory and in several States.

\section{Act Not a Code: Vague Concepts Remain}

The Native Title Act 1993 (Cth) (NTA) is virgin territory. By no means does it clarify the many broad and elastic concepts in Mabo itself. It adopts the judicial legislation (whatever it may eventually mean) and makes it 'a law of the Commonwealth' (ss.12 and 223). There is no definition of 'native title' or of those who may claim it. On the point of eligible claimants, the Mabo judgments wander to and fro among 'indigenous inhabitants', 'clan or group', 'native peoples', 'community',

${ }^{1}$ Mabov Queensland (No 2) (1992) 175 CLR 1 at 67 per Brennan J.

John Forbes is Reader in Law at the University of Queensland. 
'family, band or tribe', 'society' and other similarly imprecise expressions. As to the content of native title, we are left with judicial advice that it may range from something like freehold to an occasional right of way. Its content is a matter of evidence in every case, and findings of fact in one case are not a precedent for any other. '[I]ts incidents and the persons entitled thereto are ascertained according to the laws and customs of the indigenous people who, by those laws and customs, have a connection with the land. It is immaterial that the laws and customs have undergone some change since the Crown acquired sovereignty provided the general nature of the connection between the indigenous people and the land remains. ${ }^{2}$ We are told that native customs may continue to evolve up to the time of a claim and may survive European influences such as the 'profound' effects of Christianity, the use of schools and other modern facilities and (in the case of the Murray Islanders) a change from ${ }_{3}$ gardening and fishing to a cash economy largely dependent on the public purse.

\section{Extensions to Mabo}

In some respects native title is inferior to other land rights known to Australian law, but in other respects it is superior. On the side of inferiority, even if it resembles freehold or long-leasehold title it cannot be alienated by way of sale or mortgage (in some, perhaps many, cases it may fall far short of normal freehold or leasehold rights). But in other respects it is superior to freehold title. It cannot be subjected to mining or other developments authorised by government until a 'right to negotiate' has been exercised (ss.26-54). In the case of mining developments native-title holders and mere claimants have four months to negotiate with an intending explorer or developer. In return for their consent they may seek payments based on income or profits of the venture (ss.33, 35(a)). If four months elapse without agreement, either party may ask the Native Title Tribunal to arbitrate. 'The Tribunal is to 'take all reasonable steps' to decide within a further four months (s.36(1)(a)). Capitulation by would-be developers aside, the additional delays may vary from twelve to 24 months (The Australian, 8 February 1994, p.39; 28 February 1994, p.19). Commonwealth spokesmen are at pains to point out that the 'right to negotiate' is not a veto, but it remains to be seen whether this is a semantic distinction without a real difference. Aboriginal interests are still pressing for a veto strictu sensu (The Australian, 17 January 1994, p.2; 28 January 1994, p.4).

The limitations of 'Mabo title', as described by the judges, were significantly relieved by late amendments to the Native Title Bill. The legislation enables nativetitle holders to make an agreement with the Commonwealth or a State to exchange their title for 'a freehold estate in any land, or any other interests in relation to land, that the native title holders may choose to accept' (s.21(3)). The hitherto inalienable title would thus become available as security or as a marketable form of realty.

\footnotetext{
2 Mabo at 70 per Brennan J.

3

Id. 192 per Toohey J.
} 
There is nothing in the Act (although there may be something in government practice) to prevent a minor form of native title being quietly exchanged for a much more valuable freehold or a long-term Crown lease. Contrary to a clear statement by Justice Brennan in Mabo itself, mining leases do not extinguish native title (ss.15(1), 231, 232, 238).

\section{Special Judicial Arrangements}

Disputed claims of native title or for compensation will be adjudicated in the Federal Court or in a State equivalent approved by the federal minister. Unopposed claims and objections to new developments on established (or alleged) native title land will be processed by a National Native Title Tribunal or other approved body (ss.26ff, 107ff, 251(1)). Mere claimants of title may lodge objections and impose the attendant delays if they are registered as such (ss.29(1)(b), 186).

For present purposes the Federal Court is constituted in a most unusual way. It is exempt from the rules of evidence (s.82(3)) - a provision that often applies to administrative tribunals but rarely, if ever, to 'real' courts. In these circumstances the rules of evidence cannot be 're-inserted' on appeals based on points of law. Further, the Court must 'take account of the cultural and customary concerns of Aboriginal peoples' (s.82(2)). Since it would obviously be bound to do so if normal evidence of those things were presented, this presumably means that the Court may take judicial notice (that is, give evidence to itself) on those wide and nebulous topics. Normally, judicial notice is a very limited source of evidence. There are two good reasons for that rule. The parties may not know exactly what the court is telling itself, and it could be very difficult to talk the self-informing judge out of the natural feeling that as well as being a fine judge he is also an unusually good witness!

These are not the only departures from normal court procedure. The Court is to be assisted by a professional 'super witness' and potential de facto adjudicator described as an 'assessor'. These provisions are seen as a considerable advantage to claimants ${ }^{6}$ and as a commensurate handicap to respondents. However, in the light of other problems mentioned below they may not make a great deal of difference in practice.

The composition of the National Native Title Tribunal is governed by s.110. The President, recently appointed, is a Federal Court judge. Australian politicians have a deep and abiding belief that the citizens will more readily defer to a tribunal or inquiry headed by someone entitled 'Justice'. Non-Presidential members of the Tribunal will include 'assessors' (as described above), some people with 'special

${ }^{4}$ Id. 69 per Brennan J.

${ }_{6}^{5}$ Officially, of course, an assessor is 'not to exercise any judicial power of the Court': NTA, s.2(3).

Of such arrangements it has been well said: 'The result is in practice, as we all know, that a (representative) is a partisan and an advocate rather than a judge ... It is not easy to imagine a less satisfactory tribunal, viewed as judicial body'. In re Skene's Award (1904) 24 NZILR 591 at 597-8 per Denniston and Chapman JJ. 
knowledge in relation to Aboriginal ... societies', and others chosen by the federal executive. Special-purpose tribunals, even when they are not staffed by enthusiasts, rapidly become part of the 'club' or 'industry' concerned.

\section{Nature of Evidence in Native Title Actions}

There is little point in fine theoretical analysis that ignores the manner in which native title is likely to be proved, or that glosses over difficulties likely to arise for nonclaimant parties.

Lay or 'traditional' evidence. Evidence for claimants will consist of 'lay' evidence and 'expert' evidence. The lay evidence will include assertions about customs, tribal practices, territorial boundaries and so on. The expert evidence (in this special field) will reiterate the lay evidence and reinforce it with purported scientific findings. Normally hearsay from lay witnesses is not permitted to re-emerge as the stuff of expert opinion. In June 1994 a Sydney barrister with experience in the Northern Territory told the present author:

There are very few empirical facts when you're dealing with anthropologists. They repeat what they say someone else has told them. The hearsay of claimants is fed through an anthropologist and emerges as 'expert evidence'. The 'facts' of an anthropologist are commonly what a client or study-subject told them about perceived rights or wishes.

In the nature of things the lay evidence will often be self-serving hearsay, extremely difficult to cross-examine or assess, even if - in the club atmosphere which special tribunals develop - it were deemed 'correct' to attempt such an exercise. As a former Supreme Court judge has pointed out, alleged laws and customs 'are likely to be recalled in a manner favourable to the claimants which is, after all, simply human nature' (Courier Mail, 14 September 1993).

Elusiveness of hearsay on hearsay. Evidence and practice in the Northern Territory land rights tribunal, which has operated for some 16 years, gives a fair indication of what to expect in litigation under the new federal Act. A Queen's Counsel experienced in Northern Territory cases describes some remarkable forms of hearsay that are received in that jurisdiction, including 'group evidence' which lends itself to 'collaboration and concoction' (Hiley, 1989:195; see also Maddock, 1983:93).

If and when cross-examination is tolerated, it will still be extremely difficult to test direct evidence (let alone hearsay) if the non-claimant parties have no access to alternative versions. It is uncertain whether the new adjudicators will take well-tried precautions in dealing with assertions that are easy to make and well nigh impossible

${ }^{7}$ In the Tribunal cross-examination requires leave: NTA s.156(5). 
to check, or with the evidence of 'experts' whose scientific detachment is questionable. They were taken by the Supreme Court judge who conducted the 'grassroots' inquiry in Mabo (Moynihan J of Queensland) but the High Court paid remarkably little attention to his pointed comments on matters of credit. Moynihan J suspected that evidence of certain 'immemorial customs' owed a good deal to The Drums of $M e r$, an adventure tale by Ion Idriess published in 1941. The judge was 'not impressed with the creditability of Eddie Mabo' who seemed 'quite capable of tailoring his story to whatever shape he perceived would advance his cause'. careful perusal of the High Court judgments will not alert the reader to these comments (and others of more than passing interest) by the only judge who saw and heard the witnesses.

Expert evidence: partial and inaccessible? Land-rights litigation has given birth to a new expert witness industry consisting of anthropologists, historians and other 'social scientists'. The common-law courts have always had reservations about expert evidence, particularly when dealing with new and relatively inexact sciences prone to ideological influences. Graham Hiley $\mathrm{QC}$ reports that non-native parties have great difficulty in gaining anthropological assistance or advice; he notes the 'resentment' and 'alienation from his peers' facing any anthropologist who dares to cast doubt on a native title claim. After the Territory tribunal had been in operation for almost ten years, he could not recall a case in which a respondent to a claim had called such a witness, and there had been 'an understandable reluctance by anthropologists to be seen to be advising parties other than Aborigines' (Hiley, 1989:1945; see also Hiley, 1985, 505-06).

Despite strong temptations to self-censorship there is evidence to support Hiley QC. In June 1994 a Sydney barrister who regularly appears in the Northern Territory land rights tribunal told the author:

I was involved in an Aboriginal land claim and I rang round various universities to try and get an expert witness and no one would be in it. They were worried about their promotion. A couple of them said that they would never ever get a permit to go on to any Aboriginal land again to do work, and they would be effectively blackballed in their profession. And that's a real problem that respondents face in these applications.

Lawyers aside, some of the realism is provided by relevant social scientists, in the impressive form of admissions, some conscious, some unwitting. In March 1993 the President of the Australian Anthropological Society was reported as saying that 'most anthropologists are more comfortable working for Aborigines than in some situation where they could be construed as working against their interests' (The Aus-

\footnotetext{
${ }^{8}$ Findings of Moynihan J dated 16 November 1990: 'Determination Pursuant to a Reference of 27 February 1986 by the High Court of Australia ... Vol. I (mimeo 227 pp) at 60.

9

Id. 79,70 .
} 
tralian, 5 March 1993, p.23). He was not the first of his profession to say so. At the Kakadu inquiry in 1991, an anthropologist employed by the Northern Land Council declared that the primary duty of experts like himself was 'to represent the people they work with'. He added that if he strayed into scientific detachment and disagreed with the Land Council's position he would be liable to lose his job (Brunton, 1992:51). In such circumstances there need not be positive falsehood; embarrassing information may simply be suppressed.

These admissions are quite consistent with the Revised Principles of Professional Responsibility of the American Anthropological Association:

Anthropologists' first responsibility is to those whose lives and cultures they study. Should conflicts of interest arise, the interests of these people take precedence over other considerations. . . (Australian Anthropological Society Newsletter, June 1990, p.44)

No exception appears to be made for occasions when sworn evidence is required and when other people's interests may be at stake. Plainly these directives expose anthropologists to embarrassment if they are at all sceptical about native title. Scepticism would also expose them to prejudice in the public sector upon which they depend for employment: universities, government departments, Land Councils and kindred institutes where pressures to be 'correct' are strong.

Dr Peter Sutton, a specialist in Aboriginal affairs, acknowledges that 'the closed ranks of anthropologists larel denying [miners] access to . . scientific expertise' (Sutton, 1982:21). His colleague Professor Maddock (1989:167) is more specific:

The suspicion that anthropologists who give evidence for Aboriginal claimants are hopelessly biased is strengthened by the difficulty objectors to land claims have in getting anthropological advice ... In the Alligator River claim, the mining company Peko-EZ strongly contested parts of the claim, but the research on which they relied was carried out by a solicitor who apparently had no training in anthropology.

Maddock (1989:168) goes so far as to say that probable bias 'arises from the nature of anthropological research'. Dr Sutton (1982:22) elaborates:

The problem with a sociological diagnosis, as opposed to a medical one, is that in our culture a medical diagnosis has very little to do with a physician's politics, while a sociological diagnosis can have quite a lot to do with an anthropologist's politics.

One looks in vain for statements disclaiming the views of the American Anthropological Society and its Australian disciples. There appears to be no published material challenging the comments of Maddock or Sutton or the simple statements of fact by lawyers who cannot secure witnesses. 
It is easy to imagine the state of personal-injury litigation if the medical profession sent to Coventry any member who dared to give evidence for defendants. Outof-court 'agreements' would be common but would they commonly be free and fair? It is interesting that the Native Title Tribunal (1994:4), at its first hearing, pointed out that, whatever the state of the evidence, native titles can be created by agreement. Fears of delays, costs or lack of access to expert evidence may induce many agreements - not to mention governments with a policy of 'running dead', as the Commonwealth did in Mabo itself.

Perhaps the best prospects of obtaining rebuttal evidence will be in cases where several groups compete for the same area. The Wik claim at Weipa faces competition. In these circumstances the experts may not be quite so sure where their 'first responsibility' lies and the lay witnesses will not be univocal. But even then there may be a compromise division of spoils rather than absolution for respondents or taxpayers. It will be interesting to see how often the existence and content of native title depends on the ex parte evidence of a claimant's anthropologist or historian. A mining industry spokesman predicts that 'under the tribunal system . . . [there] will develop a loose interpretation of the Mabo decision and certainly the federal legislation provides room for that ... I think that if claims are made they will tend to be granted' (The Australian, 8 February 1994, p.43, quoting P. Ellery.) This prediction accords with Maddock's (1983:83) survey of Northern Territory cases in the 1980s: '[I]t has been usual for the Commissioner to recommend that most or all of the land claimed be granted'. On 13 May 1994 four claims for native title were pending in the National Native Title Tribunal, some in long-settled parts of New South Wales. In the event of success the air of romanticism would be intensified if roads and other services remained connected and 'traditional' hunting were pursued with rifles and four-wheel drive motor vehicles.

\section{Extinguishment Issues}

Perhaps the best chance of an even contest will occur when there is a question whether native title (if any) was extinguished before 1975. (The best advice now available suggests that compensation will not be payable in such cases.) The evidence on an 'extinguishment' issue will usually be much less woolly and it will be available to all parties on equal terms. According to the Chief Justice of the High Court the onus is on a native title claimant to prove, where required, that the title has not been extinguished by some lawful action of government in the past.

\section{Pseudo-Litigation?}

Is it really too late for some conductor of this non-symphonic work to rattle the podium and cry 'da capo? If the collective wisdom requires an expansive and primarily economic 'reconciliation' in addition to annual expenditures now in excess of $\$ 1$ billion is it necessary to wrap just one part of it in complex pseudo-litigation?

10

Coev The Commonwealth (The Wiradjun claim) (1993) 68 AIJR 110 at 119. 
The federal minister's guess is that 'Mabo' title will benefit only 5 per cent of the vaguely defined class of beneficiaries (The Australian, 11 May 1994, p.9). Taxpayers will in any event contribute to the National Aboriginal and Torres Strait Islander Land Fund, which, in conjunction with the Northern Territory Act and State legislation may well produce more 'native title' than the Mabo doctrine ever will. Taxpayers will also pay direct for any 'Mabo' titles extinguished since 1975 and for the legal services consumed by title claimants and objectors to new developments. So far relatively little has been heard about methods of ensuring that the fruits are equitably distributed by the new oligarchies: on 25 May 1994 the Courier Mail quoted a woman 'with 25 years experience in indigenous health care' complaining that 'the crumbs (are received) at grass root level' and that too much public money is 'gobbled up in administration' (p.6).

If access to evidence in native title cases is nearly so unequal as well-informed observers predict, would it not be simpler, cheaper and more candid to discard litigation and unequal 'agreements' for a simpler system of land funds and other benefits within the country's capacity to pay? The same constitutional power which has been used to 'pick up' and elaborate the Mabo decision could as well be used to replace that decision - and the litigious opportunities it provides — with a just and much more predictable scheme of assistance. Indeed, the Land Acquisition Fund which the Native Title Act has added to $M a b o$, in conjunction with longerestablished benefits, could stand in place of the nebulous uncertainties of 'native title'. A frankly administrative scheme for creating titles may be better for all concerned - 'expert' witnesses, lawyers and tribunal staff aside — than an administrative/judicial maze in which pseudo-litigation legitimises part of the expenditure by 'finding' titles on elusive evidence which is available only to those whose material, political or emotional interests it serves.

${ }^{11}$ NTA ss.17(4), 23(5), 24(2), 25(2), 54 and Part 10. 


\section{References}

Brunton, R. (1992), 'Down to Earth', IPA Review 45(1): 51-2.

Hiley, G. (1985), 'Aboriginal Land Rights in the Northern Territory', pp.491-508 in AMPLA Yearbook, AMPLA Ltd., Melbourne.

_ (1989), 'Aboriginal Land Claims Litigation', Australian Bar Review 5: 187-98.

Jackson, D. (1994), 'The Lawmaking Role of the High Court', Australian Bar Review 11: 197-213.

Maddock, K. (1983), Your Land Is Our Land, Penguin Books, Ringwood.

_ (1989), 'Involved Anthropologists', pp. 155-76 in E. Wilmsen (ed.), We Are Here, University of California Press, Berkeley.

Mason, Sir A. (1993), 'Putting Mabo in Perspective', Australian Lawyer 28: $23-8$.

Native Title Tribunal (1994), 'Introductory Notes for Mediation Conference 14 May 1994' (The Wellington Common claim).

Sutton, P. (1982), 'Anthropology Outside the Universities in Australia', Australian Anthropological Saciety Newsletter, 15 June. 